\title{
Strain Accumulation Study of Ni-based Anode-Supported Solid Oxide Fuel Cells under Partial-Redox Cycling Conditions
}

\author{
Lou Kang ${ }^{*}$, Wang Fenghui, Lu Yongjun, Zhao Xiang \\ Department of Engineering Mechanics, Northwestern Polytechnical University, Xi'an 710129, CHINA \\ "E-mail: fangou@mail.nwpu.edu.cn.
}

doi: $10.20964 / 2016.07 .28$

Received: 7 April 2016 / Accepted: 19 May 2016 / Published: 4 June 2016

\begin{abstract}
Partial-redox cycles lead to severe degradation (electrolyte cracks) to Ni-based anode-supported solid oxide fuel cell (SOFC) when the cycle number is high $(\sim 10)$, even though the oxidation degree is below the critical level ( $50 \%)$. Time controlled partial-redox cycles were implemented in SOFCs to investigate the effect of strain accumulation. It is found that this "partial-redox" cycle in which anode was oxidized partially (10\%-40\%) and then fully reduced, may bring irreversible cell expansion and mechanical damage, although it showed hardly any crack in the first few cycles. This phenomenon requires a more rigid re-oxidation level of restriction for those NASCs designed living through dozens or even hundreds of redox cycles. Strain accumulation effect was observed when the anode reoxidation degree reached ca.20\%, below which the cell was "safe". Both $\mathrm{NiO}$ and porosity gradient along anode thickness arise. SEM studies reveal that the redox front moves towards the electrolyte as redox cycle number increases, although the re-oxidation degree is constant. And the chemical reactions are considered the driving force for redox front move, which constantly bring irreversible strain to the anode.
\end{abstract}

Keywords: Solid oxide fuel cell; Partial-redox; Strain accumulation; Redox front; Chemical driving force

\section{FULL TEXT}

(C) 2016 The Authors. Published by ESG (www.electrochemsci.org). This article is an open access article distributed under the terms and conditions of the Creative Commons Attribution license (http://creativecommons.org/licenses/by/4.0/). 